\title{
ARQUIVOS DE MEURO-PSIQUIDIRII
}

Volume 33 - N.0 3

Setembro de 1975

\section{MICROSURGICAL NERVE SUTURES IMPROVE REHABILITATION AND MAY PREVENT WALLERIAN DEGENERATION}

\author{
Eros Abrantes Erhart * \\ Marcus Castro Ferreira *: \\ Antonio Tedesco Marchese *** \\ Pedro Puech-LeÃo *k*k*
}

"Nerves and Nerve Injuries" by S. Sunderland ${ }^{18}$ and the symposium on operative nerve injuries and their repair, published by "The Surgical Clinics of North America", october $1972^{19}$, present the expertise of many authors on the matter. Concomitantly, Erhart and collaborators ${ }^{2-14}$ (1958 up to 1974) have reported the following observations: (i) - Human and dog nerves, after having been completely transected for a long time (one or more years) exhibited normal nerve fibers in the completely separated distal segments, because they had been maintained practically undisturbed in their natural connective tissue bed. (ii) - The results obtained with nerve sutures and or neurolysis in long-time post-traumatic nerve injuries are very encouraging. (iii) - Experimentaly it has been demonstrated that it is possible to prevent the total Wallerian degeneration that normally occurs in the distal segment of a transected nerve, by means of an adequate and properly timed microsurgical nerve suture.

These above referred observations, literature data and clinical results, which were obtained by experienced surgeons who had accompanied our experimental work and made practical use of our conclusions by operating their patients, were properly considered for developing the following modification of the nerve suture technique.

In each operation the surgeon must take great care while handling the nerve and its natural connective tissue bed, chiefly the nerve vascular supply. This is true for neurolysis and for nerve sutures.

Laboratório de Microcirurgia Experimental, Faculdade de Medicina da Universidade de São Paulo: * Prof. Adjunto, Chefe da Seção de Neuranatomia, Depto. de Anatomia; * Prof. Assistente, Depto. de Cirurgia da FMUSP, Disciplina de Cirurgia Plástica; *** Médico Assistente da Clínica Neurológica do H.C. da FMUSP, Serviço de Neurocirurgia; $* * * *$ Acadêmico de Medicina da FMUSP. 
STEP 1 - Identify the proximal and the distal nerve segments by removing all damage or scar tissue from the site of injury, but strictly maintain the stumps, as much as possible, in their natural conective tissue beds. When there is a neuroma to be excised along the nerve, cut it perpendicular to the nerve axis in two halves, so as to have a proximal neuroma and a neuroma-like structure in the distal stump extremity, as it was described by Erhart and Rezze". 1965.

STEP 2 - Using delicate forceps, grip the neuroma of the proximal stump and than the neuroma-like structure of the distal stump extremity and pull each nerve segment carefully, in order to free them from the surrounding scar tissue. With these manouvers it may be judged how much of nerve can be stretched and therefore excised, with no danger for the future nerve suture. If while pulling, the nerve segments do not move on their beds, a very carefull dissection, just of the scar area should be done, but leave the nerve as much as possible in its natural connective bed. Beware of the vasa-nervorum. They are fundamentally important for the further nerve regeneration (Erhart \& Rezze ', Lundborg ${ }^{16}$ and Almgren ${ }^{1}$ ).

STEP 3 - Preparing to pass the threads. Use always a surgical dissecting microscope, with at least $20 \mathrm{~cm}$ focus, to facilitate accurate examination, handling, threading and apposition of the future freshned nerve endings. Use for anatomical landmarks the small epineural longitudinal vessels to avoid torsions. With the help of the forceps which still remain fixed on the neuromatous structures about to be excised, stretch gently the nerve stumps, first one and then the other, in order to cut off two small rings of the epineurion outermost layer: one ring, proximal to the neuroma of the proximal stump and the other, immediately distad to the neuroma-like structure of the distal stump, so to have exposed the nerve fascicles, each one of them maintained by their own perineurion and by the remaining innermost layer of the epineurion.

STEP 4 - Pass the threads, mononylon 8 to 10 zero, with atraumatic needles. The four cardinal points - N, S, E and W- (upper, lower, inner and outer) are recommended. The threads must be placed epi-perineurally in order not to injure the nerve fascicles (Fig. 2). The site of insertion along the nerve epineurion and perineurion will be indicated by the size and type of the neuroma (see Fig. 1 - "good and bad neuromas"). It is imperative to note that any neuromatous tissue left behind may interfere with the new-growing regenerating nerve fibers from the proximal to the distal stump.

STEP 5 - The proximal and distal nerve stump extremities are cut sharply at the level where the epineurion rings were excised. Slight used razor blades are best. This statement is based on our own experimental observations. Check the freshly cut surfaces of both nerve extremities with the dissecting microscope to see that the nerve pattern fascicles exhibit a normal aspect. If neuromatous scar tissue be still present, revert to step 3 all over again. After acquiring some experience, evaluating the neuromatous disposition by its general morphology (Fig. 1 - "good and bad neuromas"), and knowing how to evaluate how much of nerve stump can be excised, these inconveniences rarely occur.

When the interval between the two stumps is too wide, two conducts may be used: (a) use of nerve grafts; (b) shortening of the limb one or bones, in order not to stretch the nerve.

Tension must always be avoided and the nerve with its vessels intact must be maintained in its bed with its surrounding tissues, as much as possible, for best results. Grafts have been used for long gaps; for smaller gaps, as suggested by Millesi et al. ${ }^{17}$, clinical series follow-up are being studied. 


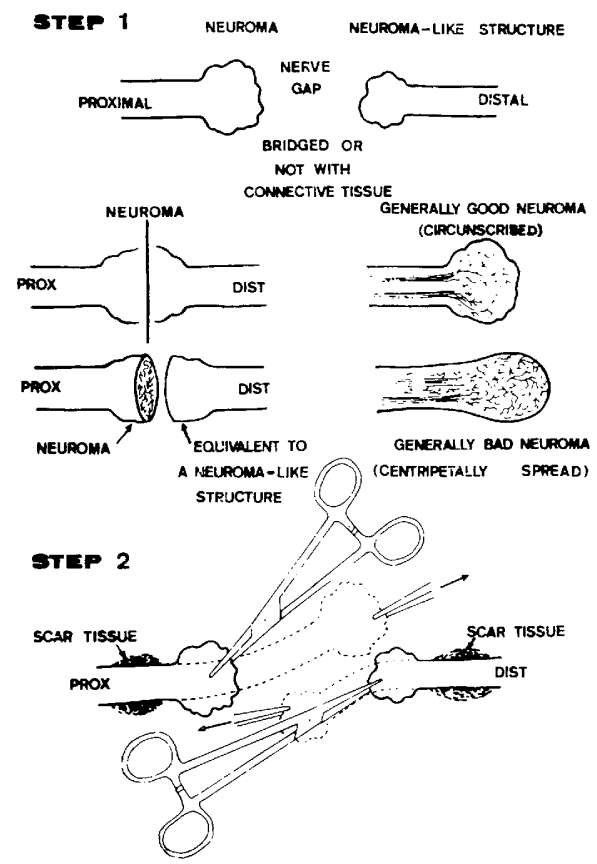

STEP 3 NERVE FASCICLES WITH
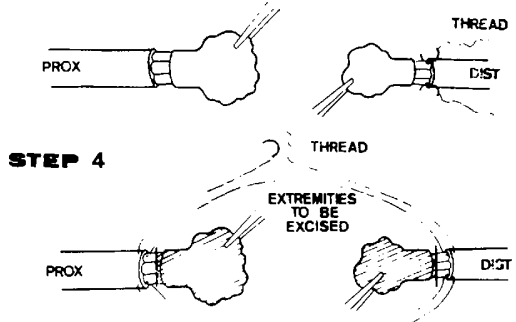

Fig. 1 - Surgical steps.

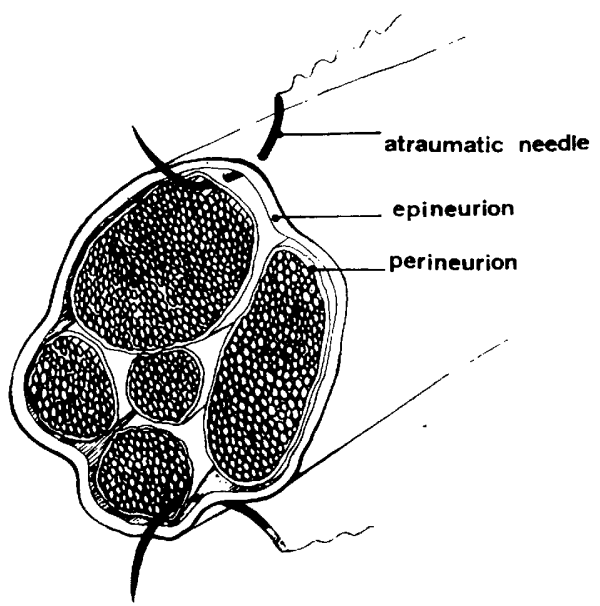

Fig. 2- Schematic drawing of what is seen with a surgical microscope while passing the threads in a stump of a recently transected nerve. 


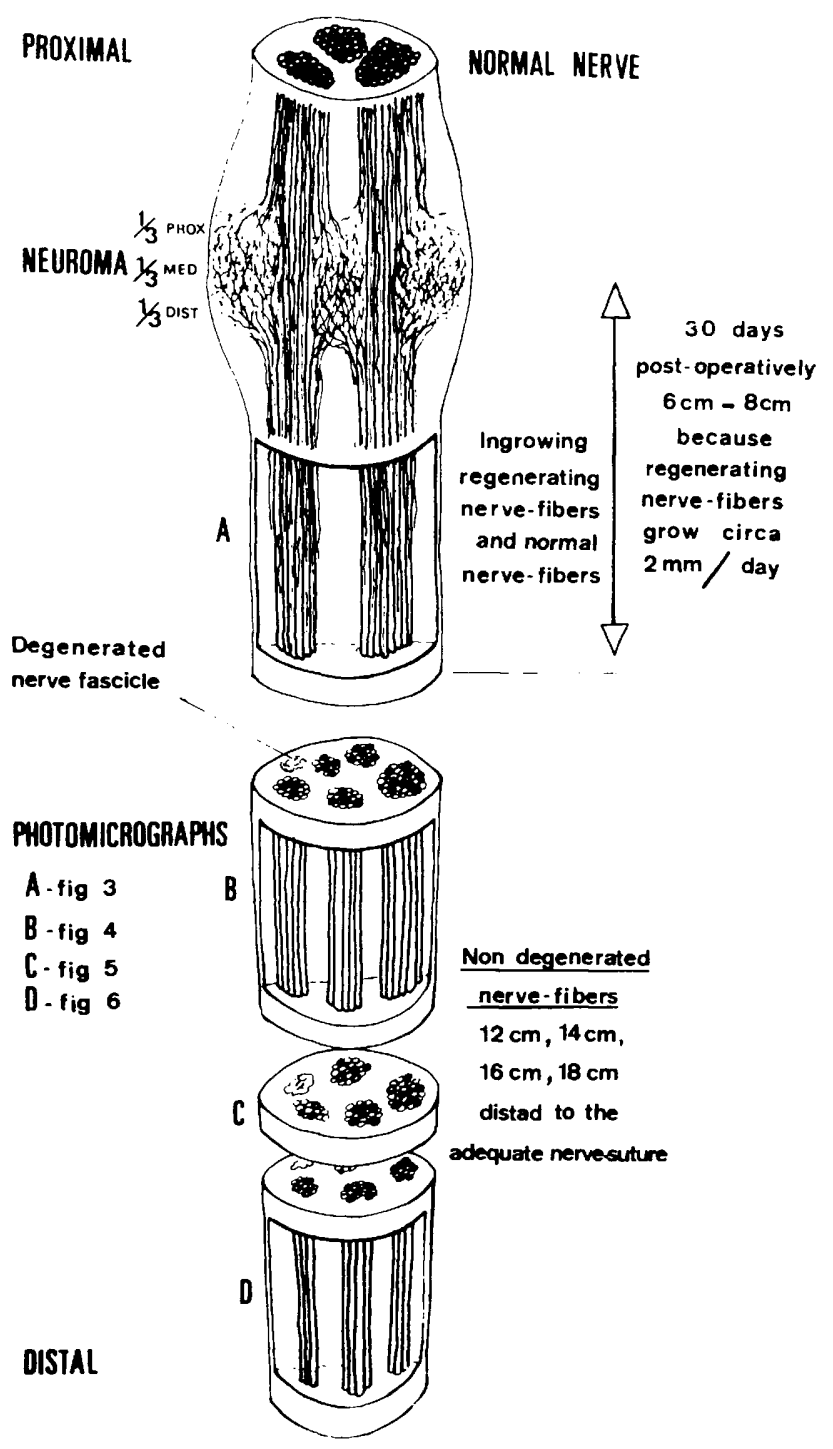

Fig. 3 - Schematic reconstruction of a nerve, 30 days after complete transection and immediately-after proper microsurgical nerve suture, showing the normal ingrowing regenerating nerve fibers and the non-degenerated nerve fibers. 
STEP 6 - Pull the threads gently together in order to join the vital nerve tissue of the proximal stump to the nerve tissue of the distal segment and, with proper tension, tie knots. The adequate tension is not too tight, nor too loose; just the right tension. More threads should be used, if necessary, to better complete the nerve suture.

STEP 7 - Recheck carefully with the microscope the end to end suture line, the nerve vascularization and the integrity of the nerve connective tissue bed.

STEP 8 - Close the wound and adequately imobilise the patient limb with plaster of Paris for 30 to 40 days.

STEP 9 - Following this, gently progressive and closely supervised physiotherapy is recommended.

This modification of nerve suture technique is being used now in clinical series. It will most certainly improve the motor and sensory rehabilitation of long-term post-traumatic nerve injuries because of the following: (i) - Distal nerve segments completely separated from the proximal stump, by complete transection, for a long time (one or more years), present normal nerve fibers (Erhart et al. $2,3,4,5,6,8,9,10,12$ ). (ii) - These fibers may repopulate long-time denervated and atrophic skeletal muscle (Erhart et al. ${ }^{9}$ ). (iii) - Long-time denervated distal bellies of the biventer cervicis muscle of the chick, when properly reoperated by cross-grafting suture with the normal contralateral muscle, lost their atrophic appearance and showed to be successfully recovered in about thirty days (Erhart et al. ${ }^{9}$ ). (iiii) - Microsurgical nerve sutures when properly performed immediately after the nerve transection, may prevent the total Wallerian degeneration that normally occurs in the distal nerve segment. This last statement is based on experimental evidences reported in a previous paper (Erhart et al. ${ }^{12}$ ) from which two schematic drawings are here reproduced (Figs. 2 and 3 ).

Finally, the clinical results obtained in primary sutures, performed following the main steps of the above described technique, are being very encouraging. In forthcoming papers these results shall be presented.

\section{RESUMO}

Neurorrafias com técnica microcimúrgica permitem melhor reabilitação $e$ podem evitar a degeneração walleriana

A presente modificação da técnica de neurorrafia, com emprego da microcirurgia, foi desenvolvida com base em trabalhos experimentais e, também, em observações clínico-cirúrgicas de pacientes portadores de lesões nervosas periféricas traumáticas, antigas e recentes. A sequência dos tempos e os cuidados cirúrgicos são descritos; aparecem esquematizados nos quadros 1 e 2. Os resultados experimentais demonstram que suturas de nervos feitas com a técnica proposta permitem melhor reinervação dos segmentos corpóreos afetados pela desnervação e podem evitar, também, quando feitas logo após a transecção do nervo, a total degeneração walleriana que normalmente 
ocorre no segmento distal à transecção. Os resultados obtidos em pacientes que estão sendo operados com esta técnica são encorajadores; serão assunto de futuras publicações.

\section{REFERENCES}

1. ALMGREN, K. G. - Revascularization of free peripheral nerve grafts. Acta Orthopaedica Scandinavica, Supplementum 154, 1974.

2. ERHART, E. A. \& ERHART, M. B. - Normal axis-cylinders in the distal segment of nerves completely separated from the proximal stump for up to 24 years. Anat. Rec. 136 (Abstracts):189, 1960.

3. ERHART, E. A. - Normal nerve fibers in the distal segment of nerves completely separated from the proximal stump for more than six months. Arq. Neuro-Psiquiat. (São Paulo) 20:289, 1962.

4. ERHART, E. A. \& REZZE, C. J. - Nerve fibers in isolated segments of dog ulnar nerves after complete brachial plexotomy and periaxilar artery sympathectomy. Arq. Neuro-Psiquiat. (São Paulo) 23:82, 1965.

5. ERHART, E. A. \& REZZE, C. J. - The neuroma-like structure of long-time severed and isolated nerve stumps. Arq. Neuro-Psiquiat. (São Paulo) 23:91, 1965.

6. ERHART, E. A. \& REZZE, C. J. - Experimental data and practical resuits which modify the present concepts of peripheral nerve fiber degeneration and regeneration. Proc. V International Congress of Neuropathology, Zurich, pp. 864, 1965. Published by Excerpta Medica.

7. ERHART, E. A. \& REZZE, C. J. - Effects of experimental devascularization on peripheral nerves. Arq. Neuro-Psiquiat. (São Paulo) 24:7, 1966.

8. ERHART, E. A. \& REZZE, C. J. - Further discussion on the "new growing" nerve fibers which repopulate the distal segment of nerves completely separated from the proximal stump for more than six months. Arq. Neuro-Psiquiat. (São Paulo) 24:91, 1966.

9. ERHART, E. A.; REZZE, C. J. \& BIAZOTTO, W. - The ectopic newly-formed nerve fibers which repopulate the long-time denervated and atrophic chick skeletal muscle. Arq. Neuro-Psiquiat. (São Paulo) 26:187, 1968.

10. ERHART, E. A.; BERARDI, A. C.; FURLANI, J.; BERZIN, F. \& BIAZOTTO, W. - New experimental data on nerve conduction patterns in vivo, determined electronically, for analysing the peripheral nerves behavior during degeneration and regeneration. Apresentado no IX International Congress of Anatomists, Leningrad, Russia, 1970. Arq. Neuro-Psiquiat. (São Paulo) 28:118, 1970.

11. ERHART, E. A. - Modified nerve suture technique improving rehabilitation of recent and long-term post-traumatic nerve injuries. Apresentado no III Pan-American Congress of Anatomy, New Orleans, U.S.A., 1972.

12. ERHART, E. A.; FERreirA, M. C.; MARChESE, A. T.; AZZE, R. \& PUECH-LEAO, P. - Suturas de nervos com técnica microcirúrgica podem evitar total degeneração Walleriana. Rev. Ass. Médica Brasileira. (Aceito para publicação em 12 de setembro de 1974).

13. FERREIRA, M. C.; ERHART, E. A.; MARCHESE, A. T.; AZZE, R. \& COSTA, R. C. - Microcirurgia de nervos: estudo experimental. Apresentado no XIII Congresso Latino-Americano de Cirurgia Plástica, Caracas, Venezuela, 1974.

14. FERREIRA, M. C.; ERHART, E. A.; MARCHESE, A. T. \& AZZE, R. Microcirurgia de nervos periféricos. Rev. Paul. Med. 84:52, 1974.

15. FERREIRA, M. C.; AZZE, R. \& BARROS ABREU, L. - Enxerto interfunicular de nervos com técnica microcirúrgica. Rev. Paul. Med. (em publicacão).

16. LUNDBORG, G. - Ischemic nerve injury. Scandinavian Jour. Plastic and Reconst. Surg., Supplementum 6, 1970. 
17. MILLESI, H.; MEISSL, G. \& BERGER, U. A. - The inerfascicular nerve grafting of the median and ulnar nerves. Jour. Bone and Joint Surg. 54A: $127,1972$.

18. SUNDERLAND, S. - Nerves and Nerve Injuries. Livingstone Ltd. London, 1968.

19. Surgical Clinics of North America - Symposium on operative nerve injuries and their repair. 52, number 5, October 1972.

Laboratório de Microcirurgia Experimental - Faculdade de Medicina da Universidade de São Paulo - Departamento de Anatomia - Caixa Postal 2921 1) 100 Sorio Paulo, SP - Brasil. 